\title{
Basal ice accretion and debris entrainment within the coastal ice margin, Law Dome, Antarctica
}

\author{
IAN D. GoODWIN \\ Australian Antarctic Division, Kingston, Tasmania 7050, Australia
}

\begin{abstract}
Basal ice stratigraphy in coastal ice cliffs at the Law Dome margin has revealed the basal accretion of clean and debris-bearing ice, marine congelation ice and granular marine ice inland of the margin. Co-isotopic analysis of $\delta^{18} \mathrm{O}$ and $\delta \mathrm{D}$ isotopes together with solute chemistry were applied to determine the modes of accretion and debris entrainment. The marine congelation ice and the granular marine ice were formed from the basal freezing of desalinated sea water and the episodic mixture of basal meltwater and sea water, respectively. Two different debrisentrainment mechanisms were identified. Debris-band ice with debris concentrations of $6.3-33 \%$ (by volume) was formed from proglacial raised beach and shallow marine sediment incorporated by an over-riding advance of the margin. Two other debris-bearing ice types, dispersed debris-poor ice with debris concentrations $<0.3 \%$ (by volume) and laminated debris ice with debris concentrations $0.9-1.9 \%$ (by volume) were accreted further inland from the margin by basal regelation processes associated with the Robin (1976) heat-pump effect.
\end{abstract}

\section{INTRODUCTION}

Numerous studies of basal debris-ice sequences in temperate glaciers and, to a lesser extent, in sub-Arctic and Arctic glaciers have been recorded in the literature, including a comprehensive discussion on the characteristics of debris in ice by Hubbard and Sharp (1989). However, there have been few rigorous studies of basal debris-ice sequences in the East Antarctic ice sheet largely because of their inaccessibility. Inland deep drilling at Byrd Station (Gow and others, 1979) obtained a complete $5 \mathrm{~m}$ thick basal ice sequence extending to the ice-bed interface with debris concentrations between 4.7 and $5.9 \%$ by volume. Other deep-drilling projects have not reached the basal zone. There have been observations of basal ice cropping out in valley glaciers in Victoria Land, near McMurdo Sound, but even fewer observations in the coastal ice margin of the East Antarctic ice sheet. Yevteyev (1959) reported detailed debris-volume concentrations in the ice margin abutting the Bunger Hills, Gaussberg, and at Mirnyy, with debris concentrations in the range $0.1-11.8 \%$ by volume. Lorius (1968) reported the basal ice characteristics without debris concentrations in the coastal region of Terre Adélie near Dumont d'Urville. Anderson and others (1980) summarized the published sightings of sediment-laden icebergs off the East Antarctic coast and reported sediment concentrations in icebergs off the George V Coast in the range $1.8-3.0 \%$ by volume. This paucity of published debris-ice characteristics from the margin of the East Antarctic ice sheet reflects the morphology of the marine terminus and the rarity of terrestrial margins where the basal zone crops out above sea level.
Hollin and Cameron (1961) described a terrestrial exposure of the basal ice zone forming the Løken Moraines at the Law Dome ice margin where it abuts northern Windmill Islands near Casey Station (Fig. 1).

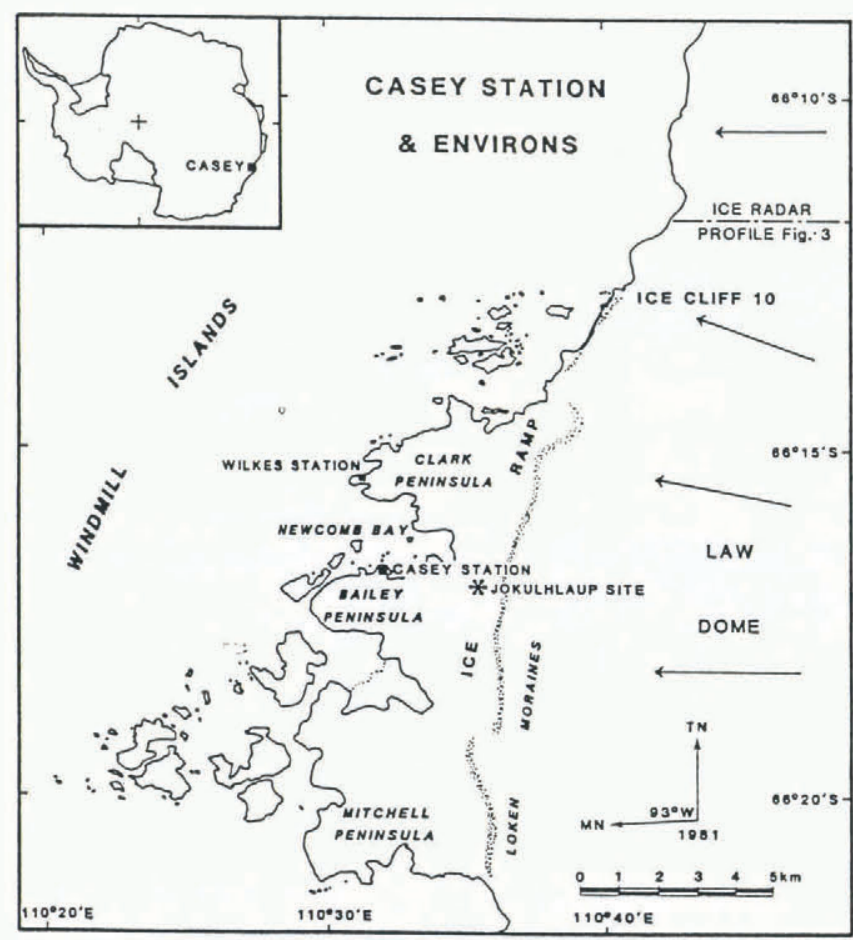

Fig. 1. Location map of the northern Windmill Islands and the Law Dome ice margin. The approximate ice-flow direction is denoted by the solid arrows. 
The Løken Moraines lie parallel to the ice margin and intersect the marine ice cliffs to the north of the Windmill Islands. These ice-cored supraglacial moraines are the surface expression of emergent basal debris bands which have been thickened at the margin by complex glacitectonics resulting in complex folding and faulting. The marine ice cliffs reveal both transverse and longitudinal exposures of the basal debris bands and adjacent basal zone ice providing a complete basal sequence, since the ice cliffs are grounded at or near sea level.

Ice-core drilling projects have been active on Law Dome since the late 1960s but have not probed the complete basal zone. Consequently, a study was initiated in 1985 and 1987 to investigate the basal ice sequences cropping out in the marine ice cliffs of Law Dome. The primary aim of the study was to determine the isotopic, chemical and debris characteristics of the basal-ice zone and to investigate the processes of subglacial ice-accretion and debris-entrainment processes occurring beneath Law Dome.

\section{GEOGRAPHIC SETTING}

The site known as ice cliff 10 (IC10) was selected for the basal ice study at the northern edge of the Løken Moraines where the basal debris-bearing ice is exposed in marine cliffs. IC10 is $28 \mathrm{~m}$ high and is grounded just below sea level (Fig. 2). The exposure reveals an upper and lower, stacked debris-rich ice sequence separated by a folded green translucent ice and light green bubbly-ice sequence. Above the upper debris-rich sequence, a third stacked debris-rich ice sequence emerges beneath a boulder-strewn supraglacial moraine. The curious green ice sequence was also observed cropping out in adjacent ice cliffs over a distance of $3 \mathrm{~km}$ and resembles the green

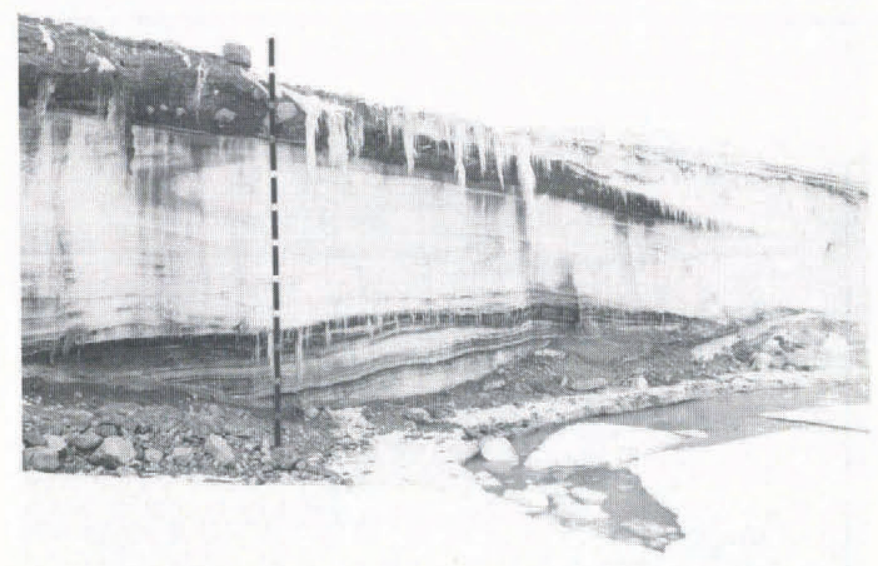

Fig. 2. The ice cliff 10 (IC10) exposure perpendicular to the ice-flow direction showing the upper and lower debris bands and folded ice of marine origin. The upper debris band is enclosed by a single fold. A proglacial talus fan lies on the multi-year sea-ice foot. The sampled profile is also shown.

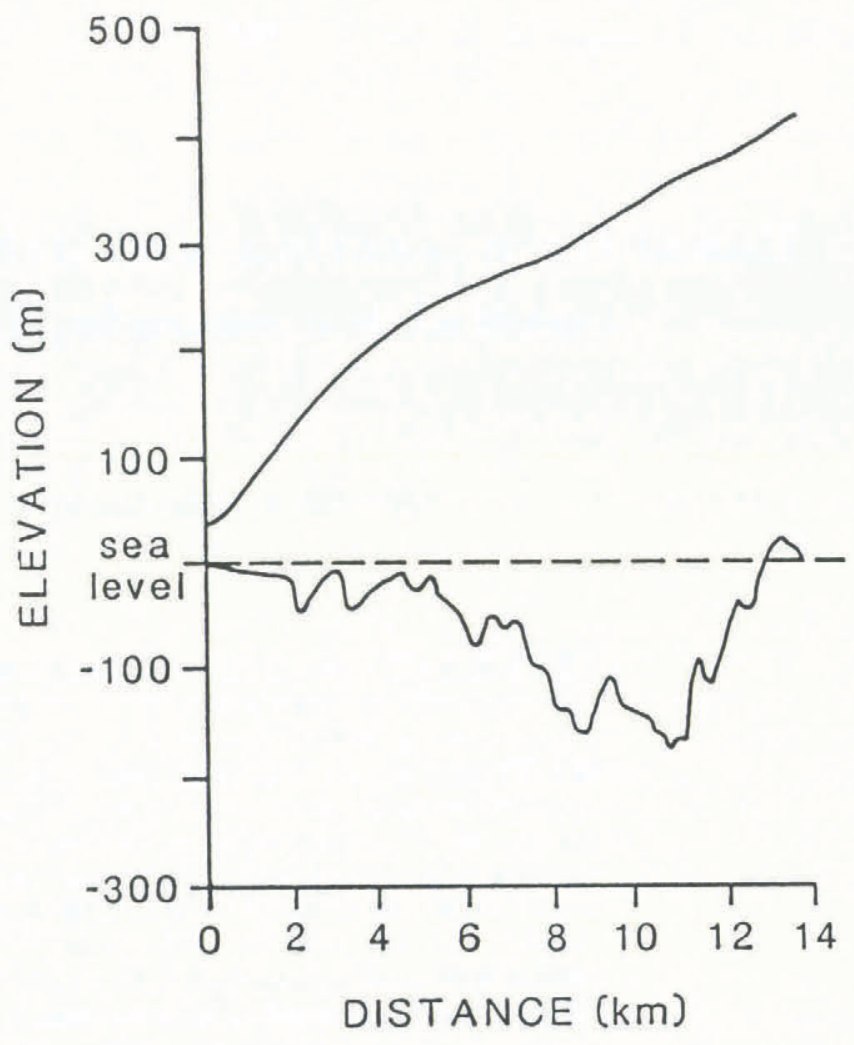

Fig. 3. Surface and bedrock profiles inland of ice cliff 10 (IC10) showing deep bedrock troughs below present sea level.

icebergs which have been observed on occasions in Antarctic waters.

To the north of IC10, the Law Dome ice margin is grounded below sea level and to the south it is grounded mainly above sea level where the elevation of the subglacial bedrock is in the vicinity of $50-100 \mathrm{~m}$ above present sea level. The higher subglacial relief is the inland extension of the exposed Windmill Islands and is responsible for the low ice velocities: less than $1 \mathrm{ma}^{-1}$ observed $2 \mathrm{~km}$ inland of the Clark Peninsula margin, and approximately $5-10 \mathrm{~m} \mathrm{a}^{-1}$ north of IC10. The approximate flow directions are shown in Figure 1. The majority of ice is discharged to the north and south of the Windmill Islands.

A profile of the ice surface and subglacial bedrock topography inland of IC10 is shown in Figure 3. The profile shows that the bedrock is at or below present sea level for approximately $12 \mathrm{~km}$ inland of the margin.

Goodwin (paper in preparation) reports that the present ice margin, including the Løken Moraines, has formed from an advance of Law Dome during the late Holocene. The present ice margin has advanced to within $1 \mathrm{~km}$ of mid-Holocene raised beach sequences on Clark Peninsula (Fig. 1). Using ${ }^{14} \mathrm{C}$ dating and relative lichenometry, the author has concluded that the Løken Moraines had formed by 1000 years BP. Oxygen-isotope time series from three ice cores in Law Dome indicate that a warmer climatic period than present existed between 1000 and 2000 years BP. From current studies of precipitation and temperature on Law Dome, it is consistent to suggest that precipitation was also higher 
during 1000-2000 years BP than at present. It is thought that the increase in mass balance initiated the minor advance of the Law Dome margin.

\section{ICE-CLIFF SAMPLING}

The entire ice-cliff face was sampled using a chainsaw and a $100 \mathrm{~mm}$ diameter ice drill to obtain a continuous stratigraphic sequence through the basal zone. Two $5 \mathrm{~m}$ long cores were cut from the upper and lower debris-band sequences for detailed analysis. The samples were transported frozen (below $-10^{\circ} \mathrm{C}$ ) to Australia for laboratory analysis which included: (i) co-isotopic analysis of $\delta^{18} \mathrm{O}$ and $\delta \mathrm{D}$ values, (ii) electrical conductivity of melted ice, (iii) ice crystallography, (iv) solute chemistry, including $\mathrm{Na}, \mathrm{Ca}, \mathrm{Mg}, \mathrm{K}, \mathrm{HCO}_{3}, \mathrm{Cl}$ and $\mathrm{SO}_{4}$, (v) debris volume, (vi) debris particle-size analysis, and (vii) micropalaeontological analysis. Melted ice samples were obtained primarily from interstitial debris-poor ice lenses and layers (less than $1 \%$ debris by volume) within the debris-rich ice. All the ice samples were melted in sealed jars at room temperature $\left(18^{\circ} \mathrm{C}\right)$ over a constant period of $24 \mathrm{~h}$ to ensure particle settling. Debris concentrations were measured by weight and converted to volume after the separate debris-rich ice samples were melted and the water fraction evaporated. Debris particle-size analysis was conducted using a dry-sieving method for the material coarser than $5 \phi$ and by Coulter counter for material finer than $5 \phi(63 \mu \mathrm{m})$.

\section{BASAL-ICE TYPES AND STRATIGRAPHY}

An oxygen-isotope $\left(\delta^{18} \mathrm{O}\right)$ stratigraphy is shown in Figure 4 for IC10. Detailed debris volume and layer stratig-

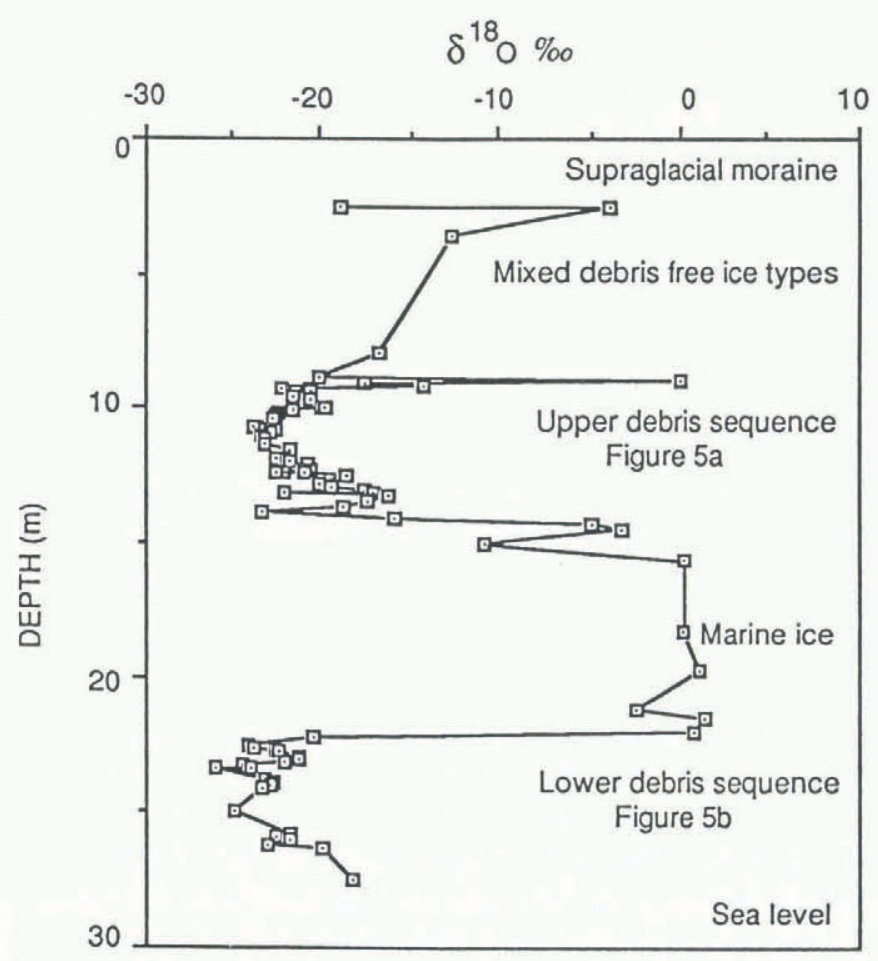

Fig. 4. Oxygen-isotope depth profile for ice cliff 10 (IC10) together with the four interpreted basal ice zones. raphies for the upper and lower debris bands are shown in Figure $5 \mathrm{a}$ and $\mathrm{b}$, respectively. The $\delta^{18} \mathrm{O}$ range for the unaltered glacier ice interbedded in the lower basal sequence and below the upper basal sequence by folding, is -26.0 to $-23.24 \%$ which corresponds to the range for Pleistocene/Holocene transition ice near the Law Dome margin (Goodwin, 1988). The $\delta^{18} \mathrm{O}$ range for the unaltered glacier ice immediately above the upper debris band is -23.0 to $-21.0 \%$. Six basal ice types were interpreted from the stratigraphy and are described below. Similar ice-crystallographic characteristics were displayed by all ice types due to the high degree of deformation in the basal zone. This has resulted in large crystals, elongated bubbles and combined shear and compression fabrics displaying multi-maxima patterns. Fault planes occur in the lower basal sequence whilst boudinage (from subsequent extensive flow) occurs in the upper debris sequence with the presence of debris-free glacier ice interlayered with the type 6 laminated debris ice. There is also extensive intra-folia folding of the type 6 ice in the thickened upper debris sequence.

\section{Debris-free ice types}

\section{Type 1. Green bubble-poor ice}

This ice has a $\delta^{18} \mathrm{O}$ range of +0.26 to $+1.56 \%$ which is similar to that for sea ice (Souchez and others, 1991), indicating a marine origin. This is confirmed by the inclusion of some biogenic material, mainly marine benthic diatoms and sponge spicules. It is bubble-free to bubble-poor, with a crystalline, optically clear appearance and conchoidal fractures through some layers. It has a green colour in situ and is most often in a layered or banded sequence with light green bubbly ice (type 2).

\section{Type 2. Light green bubbly ice}

This ice has a $\delta^{18} \mathrm{O}$ range of -16.9 to $-2.6 \%$ with samples clustered in two groups with $\delta^{18} \mathrm{O}$ ranges of -2.57 to $-4.9 \%$ and -10.86 to $-16.93 \%$. These groups correspond to ice formed from the mixture of glacial meltwater and sea water. It has a whitish green colour and is optically opaque, consisting of primarily bubble-rich ice with strong bubble elongation. In the enriched $\delta^{18} \mathrm{O}$ group, layers or lenses of optically clear bubble-poor ice similar to type 1 ice predominate.

\section{Type 3. Clean bubble-free ice}

This ice has a $\delta^{18} \mathrm{O}$ range of -23.3 to $-16.4 \%$. It is crystalline, optically clear and colourless, with very rare bubbles. It is usually found intercalated with type 5 and type 6 debris ice, forming distinct couplets in the stacked debris sequences. Typically, the clear ice occurs in thin laminae $10 \mathrm{~mm}$ thick but can occur in massive layers up to $1 \mathrm{~m}$ thick, displaying a similar crystalline appearance to type 1 ice. Very rarely it contains small rock chips.

\section{Debris-bearing ice}

\section{Type 4. Dispersed debris-poor ice}

This ice has a $\delta^{18} \mathrm{O}$ range of -23.8 to $-17.3 \%$. It has a whitish grey or dirty glacier ice appearance. It is bubbly ice with lenses of optically clear bubble-poor ice (type 3 ice) containing dispersed debris inclusions comprising fine 

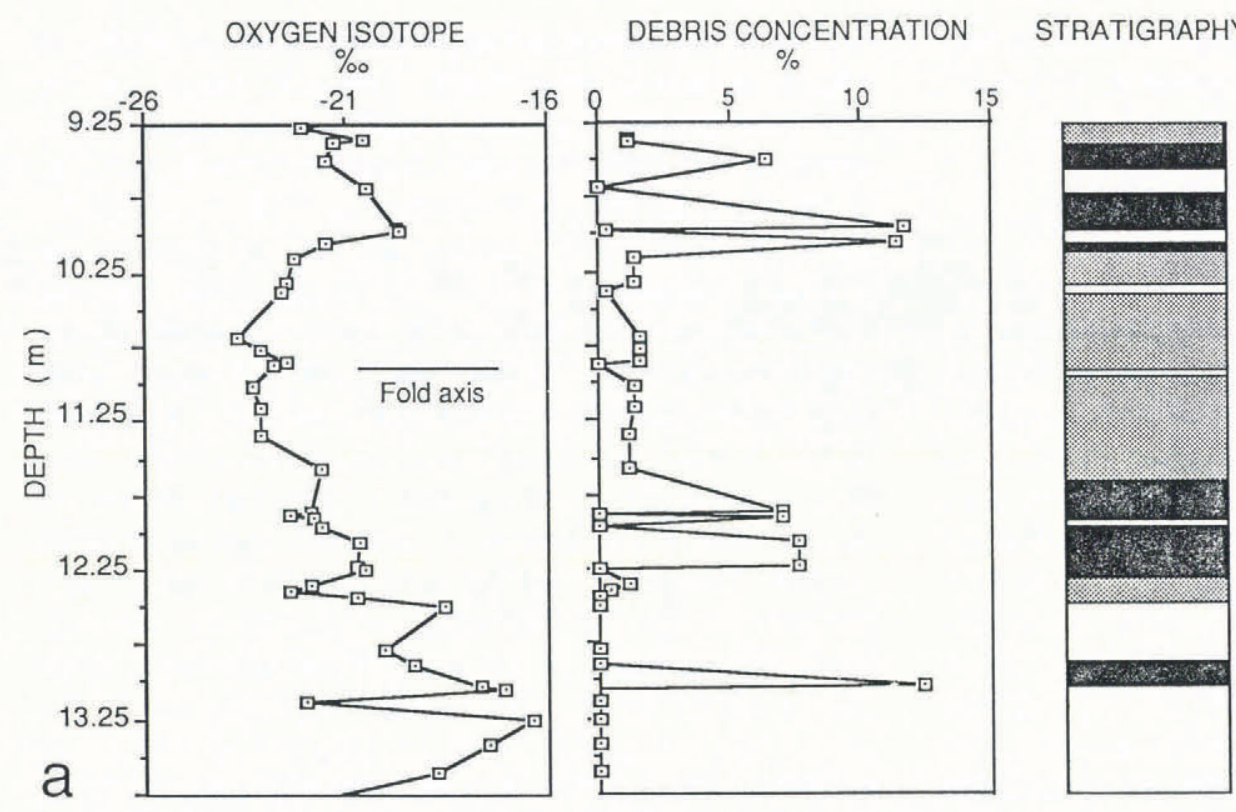

\section{BASAL ICE TYPES}

Type 3 Clean bubble - free ice

Type 5 Debris band ice

Type 6 Laminated debris ice

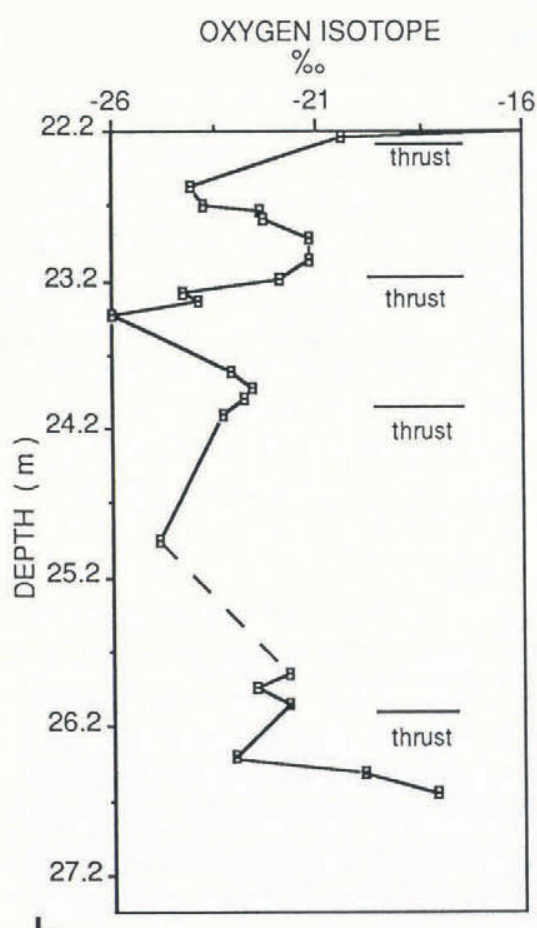

DEBRIS CONCENTRATION STRATIGRAPHY $\%$
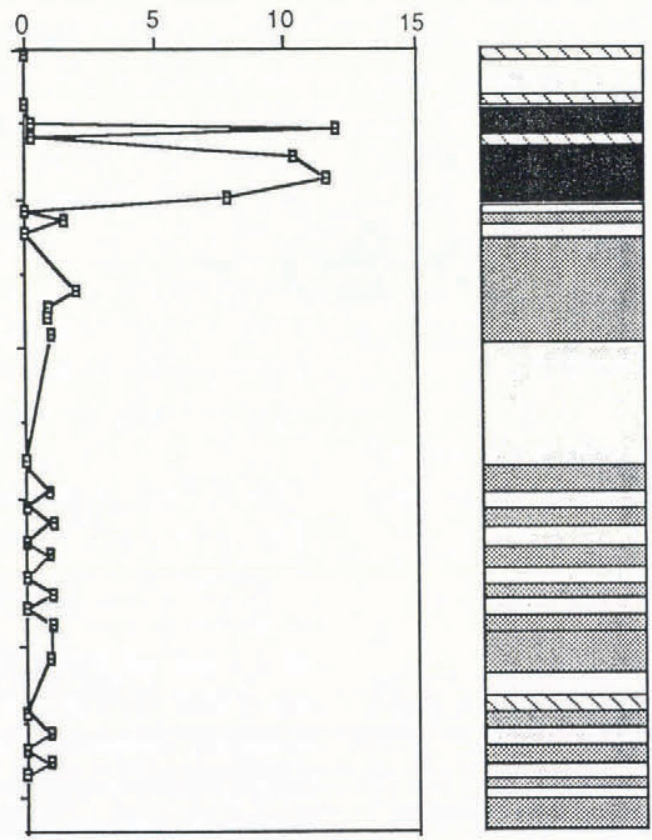

Debris free glacier ice

BASAL ICE TYPES

Type 3 Clean bubble - free ice

Type 4 Dispersed debris - poor ice

Type 5 Debris band ice

Type 6 Laminated debris ice

$\mathrm{b}$

Fig. 5. Detailed oxygen-isotope, debris concentration (by volume) and visible bulk-layer stratigraphies for the upper debris band (a) and the lower debris band (b), together with the basal ice types occurring in each band. The individual layering within the basal ice types is not shown.

debris aggregates (in concentrations less than $0.3 \%$ by volume), together with gravel and rare striated, cobble and boulder clasts. It is characterized by a strong bubble elongation.

\section{Type 5. Debris-band ice}

This ice has a $\delta^{18} \mathrm{O}$ range of -21.9 to $-17.7 \%$. It consists of bubble-free, debris-rich ice bands which are stratified with type 3 clear bubble-free ice as intercalated couplets.
The debris concentration $(<2 \phi$ size, $250 \mu \mathrm{m})$ ranges from 6.3 to $13 \%$ by volume. In the higher debrisconcentration ice, type 3 clean bubble-free interstitial ice lenses replace the alternating laminae of type 3 ice. The debris-rich ice generally occurs in bands $0.2-0.3 \mathrm{~m}$ thick, but can be up to $1 \mathrm{~m}$ thick. The thickest debris bands are intercalated with similar thickness type 3 bubble-free ice layers. The debris contains fine sandy gravel sediment similar in texture and lithology to the surficial sediment 
cover over the northern Windmill Islands. Micropalaeontological analysis of both the type 5 debris band ice and the surficial sediment samples has revealed that they contain shallow marine benthic diatoms of Pliocene or early Pleistocene age together with sponge spicules and mollusc shell fragments (personal communication from D. Harwood and P. Quilty). The debris also contains draped gravel- to boulder-sized clasts which are also found cropping out in the overlying supraglacial moraines. These clasts comprise highly polished and rounded beach boulders, rare subaerially weathered boulders exhibiting tafoni and honeycomb surfaces, together with subrounded to subangular subglacial erratics which are striated and faceted similar to those found over the northern Windmill Islands. This debris was interpreted as reworked raised beach, shallow marine and glacial sediment.

\section{Type 6. Laminated debris ice}

This ice has a $\delta^{18} \mathrm{O}$ range of -23.9 to $-20.6 \%$ which overlaps with the range for unaltered glacier ice within and adjacent to the debris sequences. It is slightly bubbly to bubble-free ice and is typically interstratified with type 3 clean bubble-free ice and type 4 dispersed debris-poor ice. The debris concentration $(<2 \phi$ size) ranges from 0.9 to $1.9 \%$ by volume. The debris is predominantly composed of gravelly fine sand together with rare angular rock fragments and sediment up to cobble clasts. It occurs as discrete thin $(\mathrm{mm})$ laminae ranging up to massive bulk layers $2 \mathrm{~m}$ thick. Generally, the layers are $0.3-0.4 \mathrm{~m}$ thick. This ice has a muddy appearance with sand particles in suspension. The debris also occurs in aggregates rather than laminae in the lowest concentrations where they fade into type 4 dispersed debris-poor ice.

Based on the range of oxygen-isotope values measured for each of the above types, it was possible to discriminate between four different sample populations. These are: marine origin type $1\left(\delta^{18} \mathrm{O}\right.$ range of +0.26 to $+1.56 \%$ ), mixed meltwater and marine origin type $2\left(\delta^{18} \mathrm{O}\right.$ range of -16.9 to $-2.6 \%$ ) , clean and debris-bearing types $3,4,5$ and 6 (overlapping $\delta^{18} \mathrm{O}$ range of -23.9 to $-16.4 \%$ ) and glacier ice $\left(\delta^{18} \mathrm{O}\right.$ range of -26.0 to $-23.3 \%$ ).

\section{CO-ISOTOPIC COMPOSITION OF BASAL ICE}

The co-isotopic linear regression analyses of deuterium $(\delta \mathrm{D})$ and oxygen $\left(\delta^{18} \mathrm{O}\right)$ isotopes were applied separately to each of the four sample populations and are shown in Figure $6 \mathrm{a}$ and $\mathrm{b}$. In this study, 42 of the 89 ice samples measured for $\delta^{18} \mathrm{O}$ content were also measured for $\delta \mathrm{D}$ content. The precision of the isotope measurements was $\pm 0.17 \%$ in $\delta^{18} \mathrm{O}$ and $\pm 0.60 \%$ in $\delta \mathrm{D}$. The unaltered glacier ice samples $(n=6)$ lie along the line with a slope of $8.2\left(\delta \mathrm{D}=8.2 \delta^{18} \mathrm{O}+13.4\right.$, with a correlation coefficient of 0.965$)$. The marine origin type 1 ice samples $(n=4)$ lie along a line with a slope of 8.1 $\left(\delta \mathrm{D}=8.1 \delta^{18} \mathrm{O}+5.8\right.$, with a correlation coefficient of $0.988)$, whilst the mixed origin type 2 ice $(n=8)$ lie along the line with a slope of $7.8\left(\delta \mathrm{D}=7.8 \delta^{18} \mathrm{O}+4.9\right.$, with a correlation coefficient of 0.996$)$. The debris-bearing ice and clean types $(n=18)$ lie along the same line with a

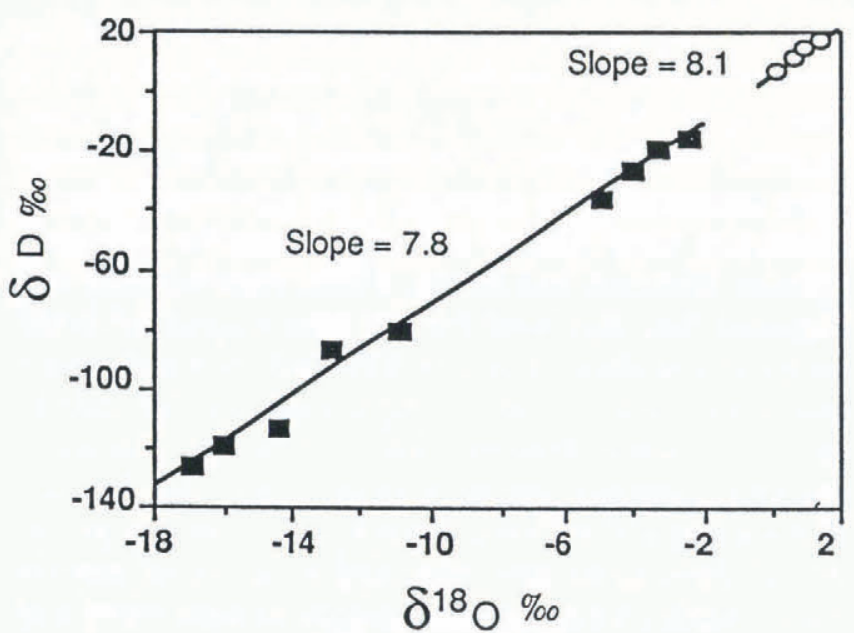

a

- Type 1 Marine origin green ice

Type 2 Mixed light green ice
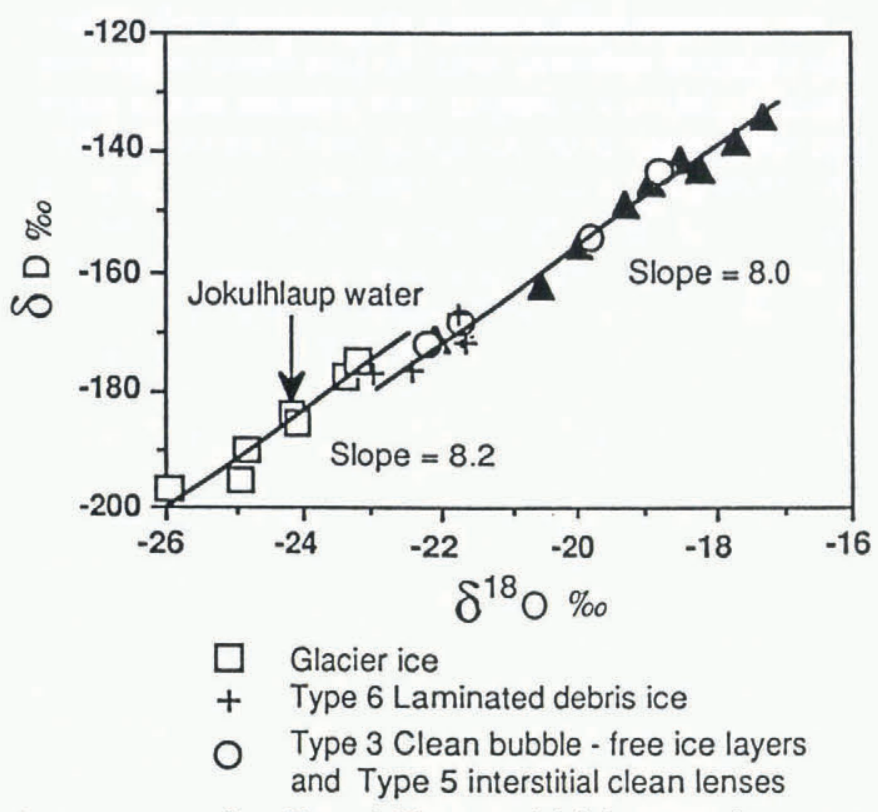

b

A Type 4 Dispersed debris - poor ice

Fig. 6. Co-isotopic plot of oxygen-isotope and deuteriumisotope values for: glacier ice, type 3 clean ice and types 4, 5 and 6 debris-bearing ice together with the jökulhlaup basal meltwater (a); and, type 1 marine origin and type 2 mixed glacial/marine origin ice (b).

slope of $8.0\left(\delta \mathrm{D}=8.0 \delta^{18} \mathrm{O}+4.8\right.$, with a correlation coefficient of 0.991).

Co-isotopic analysis has been used by numerous researchers into basal ice-accretion processes, since the technique was first applied to this problem by Jouzel and Souchez (1982). They showed that basal ice which has undergone fractionation during refreezing displays a distinct co-isotopic freezing slope which is less steep than the slope of $S=8$ (meteoric slope) for unaltered glacier ice or precipitation (Craig, 1961).

All the four sample populations have co-isotopic slopes equivalent to the meteoric slope $S=8$ for precipitation. The slight variation in slope is probably due to the small sample populations and the measurement error. Since 
these ice types display characteristics which can only be attributed to ice formed from the freezing of water in the basal zone, the lack of a co-isotopic freezing slope required investigation. It is possible that the fractionation effects were not detected if the individual refrozen increments were thinner than the composite ice layers sampled (Souchez and others, 1988). Alternatively, it is suggested that they were formed from a range of initial waters rather than an isotopically uniform water source and that the water input during freezing was isotopically lighter or more depleted than the initial meltwater reservoir (Souchez and de Groote, 1985). At the Law Dome margin, three water sources which are isotopically distinct from basal meltwater and a variety of possible mixtures exist. These are small proglacial fresh-water and brackish lakes with a range in $\delta^{18} \mathrm{O}$ of -15.8 to $-5.8 \%$, permafrost and meltwater from local precipitation with $\delta^{18} \mathrm{O}$ of -16 to $-13 \%$ and sea water in adjacent embayments with $\delta^{18} \mathrm{O}$ close to $0 \%$.

An estimate of the isotopic characteristics of subglacially produced meltwater near the Law Dome margin was obtained when water samples were collected from a major jökulhlaup event at the margin in 1985 (Goodwin, 1988). The jökulhlaup occurred approximately $7 \mathrm{~km}$ along the margin from ICl0 discharging meltwater to the ice surface. The meltwater had a mean $\delta^{18} \mathrm{O}$ value of $-24.2 \%$ and a $\delta \mathrm{D}$ value of $-184.0 \%$ which are equivalent to the mean values for the Pleistocene/Holocene transition (11000-13000year BP age) glacier ice in IC10. Consequently, the jökulhlaup water was considered to be representative of subglacially produced meltwater.

Whilst all the ice types lie along lines with the same slope, there is considerable variation in the deuterium excess value $d$ (calculated from $d=\delta \mathrm{D}-8 \delta^{18} \mathrm{O}$ (Dansgaard, 1964)) between the unaltered glacier ice and the basal and marine ice samples. The average $d$ value for the unaltered glacier ice was calculated as $10.8 \%$ from both ice samples in IC10 and from ice of the same age in a nearby borehole at BHF near Cape Folger (personal communication from $\mathrm{N}$. Young and J. Jouzel). This $d$ value for the transition ice is approximately $4-5 \%$ greater than the $d$ for the Holocene precipitation on Law Dome which is close to $6 \%$. The basal meltwater lies along the same line as that for the unaltered glacier ice in Figure 5a with a $d$ value of $9.6 \%$ which is within the measurement precision for the unaltered glacier ice. However, the basal ice types $3,4,5$ and 6 , the marine type 1 and mixed origin type 2 have average $d$ values of $4.9,6$ and $6.7 \%$, respectively, which are close to the value for Holocene precipitation. This indicates that the basal ice types have formed from the mixture of marginal Holocene water bodies with the more $\delta^{18} \mathrm{O}$ and $\delta \mathrm{D}$ depleted basal meltwaters during the ice-margin advance.

\section{MARINE-ICE CHARACTERISTICS AND ACGRET- ION}

As outlined above, the type 1 marine ice samples are clustered in a small $\delta^{18} \mathrm{O}$ range of +0.26 to $+1.56 \%$ and are interlayered with more depleted type 2 ice of mixed fresh-water and sea-water origin. The type 1 and type 2 ice layers have conductivities in the range $22-198 \mu \mathrm{S} \mathrm{cm}^{-1}$ which correspond to salinities of $0.008-0.076 \mathrm{ppt}$. Since the ice has recrystallized due to deformation, it is not possible to determine its genesis from crystallography. However, the type 1 ice is distinctive in its bubble-free, optically clear and crystalline appearance. According to Gow and others (1987), bands of optically clear or transparent ice such as type 1 only occur in congelation ice and not in other sea-ice types. Correspondingly, the $\delta^{18} \mathrm{O}$ range for the type 1 ice is similar to that for congelation ice forming beneath the Hell's Gate Ice Shelf in Victoria Land (Souchez and others, 1991). This enriched $\delta^{18} \mathrm{O}$ range corresponds to the range for frozen sea water close to VSMOW (Vienna Standard Mean Ocean Water), since the freezing of sea water results in an enrichment in $\delta^{18} \mathrm{O}$ of up to $2 \%$ for a single freezing event (Souchez and others, 1991). Morgan (1972, personal communication) reported a $158 \mathrm{~m}$ thickness of basally accreted congelation sea ice in the Amery Ice Shelf which had a similar optically transparent appearance to the Law Dome type 1 ice together with a similar $\delta^{18} \mathrm{O}$ range of 0 to $+2.3 \%$ and very low salinities of $0.015-0.020 \mathrm{ppt}$. On the basis of its $\delta^{18} \mathrm{O}$ range and optically transparent appearance, Law Dome type 1 marine ice was interpreted as being congelation ice.

The above $\delta^{18} \mathrm{O}$ range is comparable to congelation ice formed at the different geographic locations but there is considerable geographic variation in the $\mathrm{Na}$ content which reflects the relative mixing of glacial meltwater with the parent sea-water mixture and the rate of freezing. The $\mathrm{Na}$ content of type $\mathrm{l}$ ice is in the range $0.003-0.033 \mathrm{ppt}$ which is similar to that for the Amery Ice Shelf $(0.005 \mathrm{ppt})$. However, these concentrations are comparable to those reported by Souchez and others (1991) for frazil ice formed from multiple freezing events in Hell's Gate Ice Shelf (0.005-0.15 ppt) and much lower than those for congelation ice $(0.5-0.8 \mathrm{ppt})$ in the same study.

Interlayered with the type 1 congelation ice in $\mathrm{ICl} 10$ is the type 2 ice with a clustered $\delta^{18} \mathrm{O}$ range of -2.57 to $-4.9 \%$ and a similar $\mathrm{Na}$ content to type 1 ice. This $\delta^{18} \mathrm{O}$ range corresponds to the $\delta^{18} \mathrm{O}$ ranges of +1.5 to $-4.9 \%$ for desalinated sea ice formed from the cyclic melting and refreezing of marine ice in the Koettlitz Glacier Tongue, in McMurdo Sound (Gow and Epstein, 1972), and -2.5 to $-4.9 \%$ for marine ice forming part of the Strand Moraine's ice core on the west coast of McMurdo Sound (Currie, 1984). This type 2 ice is more bubbly than type 1 ice and is interpreted as granular sea ice (Gow and others, 1987) formed from parent sea water with a mixture of glacial meltwater in small quantities. The second clustered type 2 ice has a more depleted $\delta^{18} \mathrm{O}$ range of -10.86 to $-16.93 \%$ and most likely formed from a greater input of glacial meltwater with the parent sea water. Similar marine ice with an equivalent $\delta \mathrm{D}$ range -20 to $-100 \%$ which corresponds to a $\delta^{18} \mathrm{O}$ range of -3.75 to $-13.75 \%$, and a $\mathrm{Na}$ concentration of $0.020 \mathrm{ppt}$, was found by Lorius (1968) in the basal zone $500 \mathrm{~m}$ inland of supraglacial moraines near Dumont d'Urville in Terre Adélie.

The Law Dome type 1 congelation ice and type 2 granular ice do not display a freezing slope unlike the marine ice samples from Hell's Gate Ice Shelf which lie on a co-isotopic freezing slope $S=6.6$ (Souchez and others, 
1991). The lack of a displayed freezing slope may be due to the mixing of small amounts of glacial meltwater with the dilute sea water. This would imply that water heavier or more enriched in $\delta^{18} \mathrm{O}$ than type 1 ice was present prior to refreezing. Such water could only have formed from sea water which had originated from multiple melting-refreezing events, since its $\delta^{18} \mathrm{O}$ range is greater than the $2 \%$ enrichment due to a single freezing event of sea water. Multiple-freezing events of sea water would also be required to explain the very low $\mathrm{Na}$ concentrations measured in the type 1 and type 2 ice.

Prior to the late Holocene advance, it is probable that the subglacial bedrock troughs just inland of IC10 would have been marine embayments (Fig. 3). It is proposed that, as the ice sheet advanced, marine ice was accreted from these marine embayments since their orientation is roughly parallel to the ice margin where the green ice crops out in the ice cliffs. The interlayering of the type 1 congelation ice and the type 2 granular ice with its large $\delta^{18} \mathrm{O}$ range suggests that the accretion process involved the episodic input of glacial meltwater to the parent sea water. The similarity between the type 1 congelation ice and type 2 ice, granular ice with marine ice from the basal zones of a number of ice shelves, suggests that the accretion most probably occurred beneath either fast sea ice or a small ice shelf in a marine embayment near the grounding line.

Structural analysis of ICl0 (Fig. 2) showed that the debris-rich sequences are enclosed by recumbent folds whose axes intersect the sheath folded and overturned marine ice layers. It was interpreted from this sequence that the marine ice was uppermost in the accretion sequence and had been partially over-ridden by the upper folded debris-rich ice sequence.

\section{MODES OF SUBGLACIAL DEBRIS ENTRAIN- MENT AND ICE ACCRETION}

Borehole temperature measurements define a temperature gradient of $3.8^{\circ} \mathrm{C} / 100 \mathrm{~m}$ at $\mathrm{S} 1$ (ice thickness $250 \mathrm{~m}$ ) approximately $2 \mathrm{~km}$ inland of the Løken Moraines on Clark Peninsula and indicate that the basal ice is at the pressure-melting point. This is confirmed by the presence of basal water $2.5 \mathrm{~km}$ downstream at the jøkulhlaup site near the margin. However, there is the capacity for freezing at the bed since there is twice the heat loss upwards through the ice than the geothermal heat gradient can maintain (personal communication from N. Young). Consequently, as the ice thins towards the margin, the bed is in a zone of progressive freezing-on (as defined by Weertman (1961)), where extensive basal ice accretion may take place. However, the co-isotopic analysis, although in a limited data set, showed that neither the clean nor debris-bearing basal ice types displayed isotopic alteration and hence any clear evidence for the mode of accretion by bulk adfreezing of water and debris as defined by Weertman (1961). A similar case was reported for the clean and dispersed debris layers in Russell Glacier, West Greenland, by Sugden and others (1987), Knight (1987, 1989) and Souchez and others (1988). Whilst they found co-isotopic evidence for a freezing origin for the debris-band ice (similar to type 5 in this study) they attributed the unfractionated clean and dispersed debris ice (similar to types 3, 4 and 6 in this study) to a localized small-scale pressure-melting mechanism where water loss and fractionation did not occur. This process may be responsible for the Law Dome type 3 clean ice and type 6 laminated debris-ice types since their typical layer thicknesses of 0.1 and $0.3 \mathrm{~m}$, respectively, correspond to the local bedrock roughness. However, the following discussion presents evidence for another related regelation process.

The debris sequences in ICl0 significantly thicken upwards. This thickening was also observed in a longitudinal exposure of the ice cliffs together with both faulting and complex folding. The tectonics are the result of longitudinal compression of the basal ice as the flow was blocked by the relatively high bedrock elevation of the Windmill Islands. Robin (1976) proposed the pressure-melting mechanism known as the "heat-pump" effect within the basal ice mass, where excess water is formed in such high-pressure zones upstream of obstacles. The basal ice is cooled by the heat-pump effect following the squeezing of the excess water and air from the ice by the high pressure. In the downstream areas where low pressures exist, cold patches form which allow the refreezing and accretion of the squeezed water together with any other local water body. The similar large and overlapping $\delta^{18} \mathrm{O}$ range for both type $3(-23.3$ to $-16.4 \%$ ) and type $4(-23.8$ to $-17.3 \%)$ ice corresponds to the $\delta^{18} \mathrm{O}$ range between basal meltwater $(-24.2 \%$ ) and proglacial/ marginal water $(-16 \%)$. This indicates that mixtures of basal meltwater and proglacial/marginal water bodies existed prior to refreezing. Souchez and Lorrain (1978) reported that selective flushing out of ions is expected to accompany the expulsion of air and water from the basal

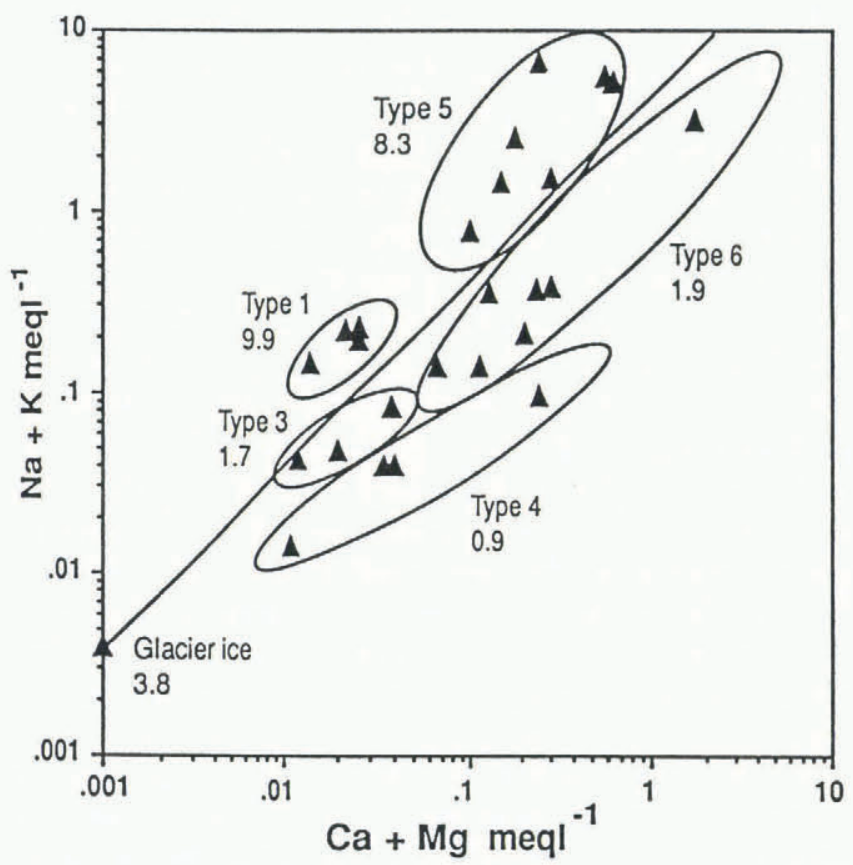

Fig. 7. Plot of alkalis $(\mathcal{N} a+K)$ vs alkaline earths $(\mathrm{Ca}+\mathrm{Mg})$ for glacier ice and the basal ice types. The molar ratio $(\mathrm{Na}+K) /(\mathrm{Ca}+\mathrm{Mg})$ value is shown for each basal ice type, and as a solid line for unaltered glacier ice. 
ice by the heat-pump effect, due to a more rapid migration of the alkalis $(\mathrm{Na}+\mathrm{K})$ into the squeezed water. This would lead to a characteristic chemistry in both the basal ice and squeezed water as described by the molar $(\mathrm{Na}+\mathrm{K}) /(\mathrm{Ca}+\mathrm{Mg})$ ratio.

Figure 7 shows the separation of ice types on the basis of the molar $(\mathrm{Na}+\mathrm{K}) /(\mathrm{Ca}+\mathrm{Mg})$ ratio. The molar $(\mathrm{Na}+\mathrm{K}) /(\mathrm{Ca}+\mathrm{Mg})$ ratio for unaltered glacier ice is 3.8 which reflects the marine origin of Antarctic precipitation. Type 4 dispersed debris-poor ice is less bubbly than glacier ice and contains lenses of type 3 clean and very low-debris concentration $(<0.7 \%)$ bubble-poor ice. These characteristics suggest that the type 4 ice has been exposed to basal squeezing processes with the subsequent migration and refreezing of small pockets of squeezed water. This is supported by the low molar $(\mathrm{Na}+\mathrm{K}) /(\mathrm{Ca}+\mathrm{Mg})$ ratio for the bubbly type 4 ice which ranges from 0.4 to 1.2 , a significant decrease from the glacier-ice value and reflects the selective flushing out of ions (alkalis) due to water expulsion or squeezing (Souchez and Lorrain, 1978). The debris in the type 4 ice includes freshly eroded fine sands and rock fragments together with striated and faceted cobbles and boulders which have been carried in traction over the bed. Lawson (1979) and Knight (1987) suggested that fine debris such as occurs in the type 4 ice may be entrained by a migration of dirty basal water into the squeezed ice away from the pressurized interface. An increase in the molar $(\mathrm{Na}+\mathrm{K}) /(\mathrm{Ca}+\mathrm{Mg})$ ratio to a range of $1.2-3.4$ is shown for type 3 clean bubble-poor ice from the type 4 ice values. This is consistent with an origin as refrozen squeezed water relatively enriched in the alkalis when compared to the squeezed ice. The molar ratio values decrease for the type 3 ice due to the inclusion of sparse bedrock chips and angular bedrock clasts which result in the preferential contribution of the alkaline earths $(\mathrm{Ca}+\mathrm{Mg})$ as observed by Souchez and Tison (1981) in subglacial meltwater. Unweathered extremely angular and homogeneous blocks of plucked local bedrock were found incorporated in the $1-2 \mathrm{~m}$ thick type 3 layers. Consequently, the type 3 ice was interpreted to have formed over a "hard" substrate. However, since the northern Windmill Islands are dominated by acid rocks, mainly granite gneisses (Blight and Oliver, 1977) with a high $\mathrm{Na}+\mathrm{K}$ and low $\mathrm{Ca}+\mathrm{Mg}$ content, it was expected that chemical weathering of the bedrock would produce a higher molar ratio in the basal meltwater. The lower than expected molar ratio in the type 3 ice may be attributed to a limited circulation of the squeezed water prior to refreezing. The type 6 laminated debris ice has a similar molar $(\mathrm{Na}+\mathrm{K}) /(\mathrm{Ca}+\mathrm{Mg})$ ratio of $1.0-2.7$ to that for type 3 ice and was interpreted to have formed from refrozen squeezed water transporting fine sands in suspension and angular rock fragments. These fine sands and rock fragments indicate that they are the product of freshly eroded bedrock by glacial crushing processes and that the type 6 ice probably accreted immediately downstream of the bedrock obstacles. The small $\delta^{18} \mathrm{O}$ range of -23.9 to $-20.6 \%$ for the type 6 ice overlaps with the range for glacier ice and indicates that this ice type was accreted from basal meltwater only which suggests an origin inland from the margin. The existence of both bubble-poor type 3 ice and bubbly type 4 ice intercalated within the type 6 layers supports the origin of type 6 ice as dirty refrozen squeezed water.

The type 5 ice displays a molar $(\mathrm{Na}+\mathrm{K})$ / $(\mathrm{Ca}+\mathrm{Mg})$ ratio which is significantly enriched in alkalis $(\mathrm{Na}+\mathrm{K})$ and ranges from 5.1 to 13.7. This enrichment in alkalis is comparable to that for type 1 congelation ice which has a molar $(\mathrm{Na}+\mathrm{K})$ / $(\mathrm{Ca}+\mathrm{Mg})$ ratio ranging from 7.4 to 10.2 . The alkali enrichment in the type 5 ice is probably derived from saturated marine sediment with a high concentration of soluble marine salts $\mathrm{NaCl}$ and $\mathrm{Na}_{2} \mathrm{SO}_{4}$ rather than from meltwater cation-exchange processes, since less than $4 \%$ of the debris is silt and less than $1 \%$ clay. This is further supported by the comparative $\Sigma+$ range for type 5 ice $\left(0.9-6.1 \mathrm{meq}^{-1}\right)$ and for the jökulhlaup water $\left(7.0 \mathrm{meq}^{-1}\right)$ with its massive alkali enrichment (molar $(\mathrm{Na}+\mathrm{K}) /(\mathrm{Ca}+\mathrm{Mg})$ ratio $=26)$. Rare localized evaporite deposits were observed on the Windmill Islands around the shores of previously saline/brackish lakes, having precipitated from trapped sea water as relative sea level lowered. Since the intercalated type 3 clean-ice layers and interstitial clean-ice lenses in the type 5 debris-band ice do not display a freezing slope, the accretion of type 5 ice cannot be attributed to bulk freezing-on. As the large $\delta^{18} \mathrm{O}$ range of -21.9 to $-17.7 \%$ o for the type 5 ice indicates a mixed water source similar to that from which type 3 and type 4 ice formed, it is likely that a freezing slope would not be detected. The interstitial type 3 ice lenses indicate that the sandy substrate was saturated and permafrosted prior to or during incorporation at the sole. The intercalated type 3 clean-ice layers in the type 5 ice represent refrozen meltwater formed on the surface of the impermeable permafrosted sediment. Tison and others (1989) discussed the entrainment of similar permafrosted near-shore and raised beach deposits into debris bands during a recent advance of glaciers in southeastern Ellesmere Island. They suggested that freezing of the upper layers of proglacial wet marginal sediment allows the sediment to be incorporated by over-riding as the glacier advanced, allowing the sediment to be transported in an englacial position. The high molar $(\mathrm{Na}+\mathrm{K}) /(\mathrm{Ca}+\mathrm{Mg})$ ratio and the similar sediment characteristics of the type 5 debris-band ice and the surficial sediment cover of the northern Windmill Islands indicate that the type 5 debris ice was accreted by over-riding close to the present ice margin. This origin is consistent with the synchronous $20 \mathrm{~km}$ near-continuous outcrop of this ice type (exposed in the Løken Moraines) along the northern Windmill Islands margin.

Knight (1989) reported a similar stacking of basal debris layers in West Greenland without bulk freezing-on, which he attributed to an unknown process. In an area of primarily compressive flow such as the Windmill Islands section of the Law Dome margin it is likely that the stacking of basal clean and debris-rich ice layers results primarily from deformation and over-riding of the basal ice rather than bulk freezing-on.

\section{CONCLUSIONS}

The basal ice types in the Law Dome margin reflect the dominant marine influence on subglacial processes along 
the East Antarctic ice-sheet margin. Consequently, it is important to distinguish between basally entrained glacial sediment from the ice sheet's interior and reworked or over-ridden marginal sediment, to determine the sediment flux from the ice sheet and indirectly glacial erosion rates. This study shows that type 5 debrisband ice with debris concentrations up to $33 \%$ by volume consists of reworked shallow marine and proglacial sediment which has been accreted near the ice margin by over-riding. Co-isotopic analysis has shown that this ice is indistinguishable from glacier ice primarily because small amounts of subglacial meltwater have been mixed with permafrost and proglacial water bodies near the margin. The type 4 dispersed debris-poor ice with debris concentrations $<0.3 \%$ by volume was identified as watersqueezed basal ice with pockets of type 3 clean and debrisbearing bubble-free ice. Type 6 laminated debris ice with debris concentrations in the range $0.9-1.9 \%$ by volume was identified as refrozen dirty squeezed water. The $\delta^{18} \mathrm{O}$ range of the type 4 ice indicates that it was accreted inland of, and near the margin, whilst the type 6 ice was found to have accreted only inland away from the margin. The gravel- to cobble-sized debris incorporated in the type 4 and type 6 ice were mainly angular bedrock fragments, indicating that they were eroded by plucking and frozen into the basal ice without further erosion in the subglacial zone downstream. The ice and sediment characteristics of both type 4 and type 6 ice were found to be more typical of the bulk of basal debris-bearing ice cropping out in other coastal East Antarctic exposures (in the Bunger Hills and Terre Adélie) and to ice formed in the interior from localized pressure melting and regelation, reported for Antarctica by Gow and others (1979) and in Greenland by Sugden and others (1987). Further detailed co-isotopic and solute analyses are required to discriminate between individual regelation layers and to determine the respective nature of basal squeezing and pressured-induced regelation processes.

\section{ACKNOWLEDGEMENTS}

The author acknowledges the field assistance of members of the 1985 and 1987 ANARE wintering parties at Casey Station. Ms D. Davies of the Australian Government Analytical Laboratories, Hobart, conducted the solute measurements and $\mathrm{Mr}$ J. Olley of the CSIRO Division of Water Resources, Canberra, conducted the co-isotopic measurements. In addition, Mr V. Morgan and Dr P. Quilty assisted with constructive discussions, and critical reviews of the first draft by Dr P. Knight and Dr J. Tison significantly improved the paper.

\section{REFERENCES}

Anderson, J. B., E. W. Domack and D. D. Kurtz. 1980. Observations of sediment-laden icebergs in Antarctic waters: implications to glacial erosion and transport. $\mathcal{J}$. Glaciol., 25(93), 387-396.

Blight, D. F. and R. L. Oliver. 1977. The metamorphic geology of the Windmill Islands, Antarctica: a prelim- inary account. 7. Geol. Soc. Aust., 24, 239-262.

Craig, H. 1961. Variations in meteoric waters. Science, 133, 1702-1703.

Currie, P.J. 1984. The structure and origin of the Strand moraines, Antarctica. (B.Sc. thesis, Victoria University of Wellington.)

Dansgaard, W. 1964. Stable isotopes in precipitation. Tellus, 16(4), 436-468.

Goodwin, I.D. 1988. The nature and origin of a jökulhlaup near Casey Station, Antarctica. F. Glaciol., 34(116), 95-101.

Gow, A.J. and S. Epstein. 1972. On the use of stable isotopes to trace the origins of ice in a floating ice tongue. 7. Geophys. Res., 77(33), 6552-6557.

Gow, A.J., S. Epstein and W. Sheehy. 1979. On the origin of stratified debris in ice cores from the bottom of the Antarctic ice sheet. F. Glaciol., 23(89), 185-192.

Gow, A.J., S. F. Ackley, K. R. Buck and K. M. Golden. 1987. Physical and structural characteristics of Weddell Sea pack ice. CRREL Rep. 87-14.

Hollin, J. T. and R. L. Cameron. 1961. I.G.Y. glaciological work at Wilkes Station, Antarctica. F. Glaciol., 3(29), 833-843.

Hubbard, B. and M. Sharp. 1989. Basal ice formation and deformation: a review. Progress in Physical Geography, 13(4), 529-558.

Jouzel, J. and R. A. Souchez. 1982. Melting-refreezing at the glacier sole and the isotopic composition of the ice. f. Glaciol., 28(98), 35-42.

Knight, P.G. 1987. Observations at the edge of the Greenland ice sheet: boundary condition implications for modellers. International Association of Hydrological Sciences Publication 170 (Symposium at Vancouver 1987 - The Physical Basis of Ice Sheet Modelling), 359-366.

Knight, P.G. 1989. Stacking of basal debris layers without bulk freezing-on: isotopic evidence from West Greenland. J. Glaciol., 35(120), 214-216.

Lawson, D.E. 1979. Sedimentological analysis of the western terminus of the Matanuska Glacier, Alaska. CRREL Rep. 79-9.

Lorius, C. 1968. A physical and chemical study of the coastal ice sampled from a core drilling in Antarctica. International Association of Scientific Hydrology Publication 79 (General Assembly of Bern 1967 - Snow and Ice), 141148.

Morgan, V. I. 1972. Oxygen isotope evidence for bottom freezing on the Amery Ice Shelf. Nature, 238(5364), 393-394.

Robin, G. de Q. 1976. Is the basal ice of a temperate glacier at the pressure melting point? f. Glaciol., 16(74), 183-196.

Souchez, R.A. and J.M. de Groote. 1985. $\delta \mathrm{D}-\delta^{18} \mathrm{O}$ relationships in ice formed by subglacial freezing: palaeoclimatic implications. F. Glaciol., 31(109), 229232.

Souchez, R.A. and R. D. Lorrain. 1978. Origin of the basal ice layer from Alpine glaciers as indicated by its chemistry. 7. Glaciol., 20(83), 319-328.

Souchez, R. A. and J.-L. Tison. 1981. Basal freezing of squeezed water: its influence on glacier erosion. Ann. Glaciol., 2, 63-66.

Souchez, R., R. Lorrain, J. -L. Tison and J. Jouzel. 1988. Co-isotopic signature of two mechanisms of basal-ice 
formation in Arctic outlet glaciers. Ann. Glaciol., 10, 163-166.

Souchez, R. and 8 others. 1991. Ice composition evidence of marine ice transfer along the bottom of a small Antarctic ice shelf. Geophys. Res. Lett., 18(5), 849-852.

Sugden, D. E. and 6 others. 1987. Evidence for two zones of debris entrainment beneath the Greenland ice sheet. Nature, 328(6127), 238-241.

Tison, J. -L., R. Souchez and R. Lorrain. 1989. On the incorporation of unconsolidated sediments in basal ice: present-day examples. Z. Geomorphol., 72, 173-183.

Weertman, J. 1961. Mechanism for the formation of inner moraines found near the edge of cold ice caps and ice sheets. J. Glaciol., 3(30), 965-978.

Yevteyev, S. A. 1959. Opredeleniye kolichestva morennogo materiala, perenosimogo lednikami vostochnogo poberezh'ya Antarktidy [Determination of the amount of moraine material carried down by glaciers of the east coast of Antarctica]. Informatsionnyy Byulleten' Sovetskoy Antarkticheskoy Ekspeditsii 11, 14-16.

The accuracy of references in the text and in this list is the responsibility of the author, to whom queries should be addressed. 